\title{
構工法知識と建物情報との分離による施工シミュレーション手法 SIMULATION USING CONSTRUCTION METHODS WHICH ARE SEPARATED FROM DESIGN INFORMATION
}

\author{
片岡 誠* \\ Makoto KATAOKA
}

\begin{abstract}
There has been a lot of research on and release of commercial systems that enable evaluation and visualization of alternate construction methods. These have enabled the selection of good construction plans. However, the process in which engineers build 3D geometry, formulate a schedule and eventually synchronize them is still a time-consuming process. Changing any aspect of the geometry or the schedule and re-linking them is also time-consuming. Therefore, the engineers may compromise on getting the best solution. This paper describes a technique to automate the generation of multiple sets of schedules, quantity takeoffs and 4D visualization from a single 3D model.
\end{abstract}

Keywords: Construction method, Construction planning, Quantity takeoff, Scheduling, Knowledge-base, 4D simulation 構工法, 施工計画, 積算, スケジューリング, 知識ベース, 4 次元シミュレーション

\section{1.はじめに}

施工計画において多数存在する構工法のうち，いずれを採用する かは, 施工計画者の経験から判断しうる範囲に限られることが多く, 自ずと一案件に対する選択肢は少数に限られる。その結果, 多数の 構工法について計画されたなら得られたであろう最適解とは異なる 構工法を選択する可能性は高い。そうかといって, 多数の構工法に ついての計画を作成し比較検討しようとすれば，計画に費やされる 時間と労務が増大するのは言うまでもない。結果, 施工計画者はそ れまでの経験から大まかな方針として，2，3の構工法を選び，工 期とコストの試算と, 施工性の難易の予想をもって採用構工法を決 定することになる。

いわゆる施工計画とは, 設計に続く, 施工の前段階もしくは初期 段階に行われる工法や工程の計画プロセスを指すが，設計段階で あっても設計者は設計者なりに部分的な施工計画一それが施工者の 持つ最新の技術を網羅したものでなかったとしても一を経て構法を 決定しているのであり，施工計画行為が完全に設計と分離している わけではない。設計から施工，場合によっては運用までも含めて， 最適解を得ようとする努力がなされる現状においては，むしろ，設 計段階で施工の知識を活用する効用は大きい。実際に, 設計施工一 貫方式であっても, 分離方式であっても, 施工の観点から品質, コ
スト等を考慮した結果, 設計変更がなされることは多い。まして設 計段階のうちに多様で最新の知見をも含む施工知識を盛り込むこと が可能であるなら，その効果はさらに大きいものになる。つまり， 設計段階，より正確に言えば設計段階の中でも構法を決定する前の 段階において，多様な構工法についての施工管理の難易，ひいては 完成建物の品質を予測し，工期やコストを試算する仕組みが提供さ れれば，設計と施工とを統合したよりよい建築生産環境を実現する ことができる。設計と施工が専門分化した結果生じてきた弊害を克 服するための一つの解決方法となりうる。

本論文は，単一の建物情報に複数の構工法を適用する仕組みを実 現するための理論的な方法を提案するものである。さらに，そのた めの要素として, 建物情報の記述方法および個別の案件に一切依存 しない構工法定義の記述方法を提案する。具体的には，建物情報に は完成建物形状の幾何情報のみを持たせ，構工法に依存する情報は これから排除しておき，あらかじめ記述しておく構工法定義をこの 建物情報に適用することで，その構工法に合った部材分割と施工手 順を作成するというものである。例えば，鉄骨造における柱の継手 位置やブラケットの有無, カーテンウォールの材料やユニット割り， さらに基本的な $\mathrm{RC}$ 造か鉄骨造かという違いによる部材の断面など も建物形状から排除する。この建物情報にある種の「鉄骨造」を適 
用すれば，梁には $\mathrm{H}$ 鋼断面が与えられ，カーテンウォールはある幅 でユニット化され，取り付けや接合等の生産性歩掛注1)から工程が算 出されるという仕組みである。つまり, 断面や継手位置, 外壁の二 ニットなどの詳細設計がなされていなくても, 柱, 梁, 床, 壁といっ た躯体部材がどこに配置されるかが分かる程度の設計情報さえあれ ば, 施工数量, サイクル工程, リソース必要量など, 構工法を比較 検討するに足る情報を提供することを実現するものである。なお， 本論文で提案する理論および赛装技術は，一般的に本設の施工計画 に主要とされる，躯体およびこれと同時期に施工される外壁を対象 とする。

\section{2. 既往研究}

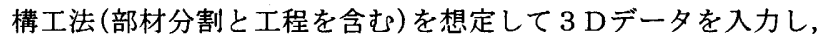
そこから数量を集計するシステムはかなり以前から存在している。 90 年代には, 別途作成した工程に 3 Dデータを割り付け, 時系列的 な表示をもって施エシミュレーションあるいは 4 次元シミュレー ションを称するシステムが提案されてきた ${ }^{1}$ 。建築施エに関する 様々な要素を統合し, 時間軸に沿って可視化した先進的な試みとし て松澤2)を挙げることができる。また，近年の情報処理環境の成熟 を受けて，嘉納 (3)自律的に行動するオブジェクトを組み合わせて 建築施エプロセスをモデル化し視覚的に表現するシミュレーション 手法を開発した。商用アプリケーションソフトにもこれらと類似し た機能を提供するものは少なくない。

これらのシステムに共通する特徴は，建物の構工法がある程度確 定したものについて,それを時系列的に可視化するという点である。 特に部材分割については，建物データを入力するためにも，事前の 定義が必要である。複数の部材を一つにまとめる操作は容易だとし ても，その逆は簡単ではない。複数の部材をグループ化した複合部 材を, 工法の変更に応じて, 組み直すこともやはり煩雑である。つ まり,これらの主な利用局面は, 自由に構工法を変更しながらシミュ レーションを行うところにではなく, 構工法までを含めて詳細な可 視化を行い，施工手順を疑似体験することで，問題点の発見を容易 にするというところにある。ひとつの設計に対して複数のシミュ レーションを行うのはいまだ簡単ではない。

ひとつの設計に対して複数の施工のシミュレーションを試みた初 めての論文を発表したのは北野4)であろう。北野は「同一の建物基 本モデルからさまざまに分節された部分構法クラスの定義と領域分 割（工区・部材分割）が生成され得ること, またこの分割が構工法 計画として一体に行われるのに応じてさまざまな工程（プロセス定 義）がもたらされること」を示した。ひとつの設計データを構工法 に応じて部品分割するというアプローチは, 根本的に従来の施エシ ミュレーションの制約から脱却することを意味する。ただ残念なが ら，施工計画知識を体系化するには至っておらず，部品分割などの 処理は構工法の知識を持った北野自身の手作業によってなされた。

米国で建設分野における情報技術利用で先端的な研究を行ってい る CIFE (Center for Integrated Facility Engineering, Stanford Univ.) においても，従来の $4 \mathrm{D}$ システムの問題を克服するために $\left.\mathrm{Akbas}^{5}\right)$ が 4 次元シミュレーションを自動的に生成するプロトタイ プシステムを開発した。Akbas は施工手順に依存するパラメータを 変更することで, 同じ $3 \mathrm{D}$ D゙ータから異なる工程を自動生成する手
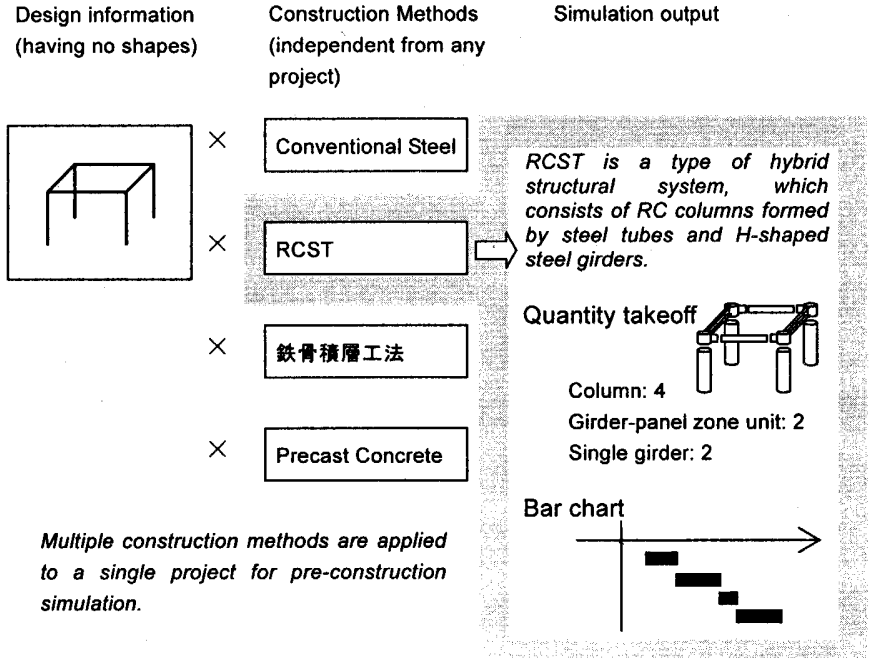

Fig.1: Separation of construction methods and design information

法を示した。ここで扱われたパラメータは，大きな面をどこからど こに向かって作業を進行させるかという作業班の移動方向を設定す ることで複数の工種がある時期に近接する領域で輻輳しないかを確 認したり, 各職種の生産性を変更することで先行職種が後続職種に よって抑えられるなどバランスを確認したりする手法を示している。 しかしながら, 選択肢はシステムによって与えられており, 施工計 画知識を編集可能な状態に置いているわけではない。

施工計画に関する知識を定式化しようとする試みは継続的になさ れてきた。大沢ら6の「施エプロセスチャート手法」は, 工程計画 に関する知識を外在化させるための有効な方法である。ここで提案 された「計画テーブル」に従うことで十分に考慮された工程編成を 実現することが可能であることを詳細に示しており，コンピュータ に実装すればかなりの部分が自動化できる可能性を㩲している。た だし, 計画過程において計画者の「検討」を必要とすることから, 完全な自動化にはさらなる研究が必要である。

本論文では，彼らが残した課題をいくらかでも解決す心゙く，施工 計画知識を外在化して体系化させるために必要な，いわば施工計画 言語の一例を示し，これが実際にコンピュータシミュレーションに よって自動的に処理されうることを示す。

\section{3. 建物情報と構工法知識の分離}

複数の構工法に応じた動的なシミュレーションのためには, あら かじめ定義された単一の構工法に依存する情報は不要である。従来 の方法では, あるシナリオ, 例えば工場で生産される部材の単位や それらの建築現場における取り付け手順が決まっていることを前提 に, 部材形状を入力している。しかし部材断面ひとつをとっても, 完全に決定されているのではなく, 構工法によっていかようにも変 わりうる。一般的な鉄骨造を採用すれば 3 層 1 節のボックス断面の 柱であるものが，別の構工法を採用するなら 2 層 1 節の円形断面の 柱として扱わなくてはならないこともある。大梁との仕口をブラ ケットで行うのか, ノンブラケットで行うのかは，接合方法によっ ても変化する。施エシミュレーションを目的とする場合, 建物情報 は構工法と分離されるほうが都合がよい。その上で，建物情報と構 
エ法の組み合わせに対して施エシミュレーションを実施する (Fig.1)。

こう考えれば, 建物情報は部材そのものを表現するものではなく， むしろ, 部材が置かれる領域を示すものとして扱われるべきである。 断面, 重量, 継手位置や, その他の構工法に依存する属性を持たな い空間領域を示し，構工法を適用した結果具体化された部材がその 領域に配置されると考えるのである。

一方, 構工法の知識には, 部材形状を含む属性, 継手配置, 施工 負荷，必要な作業，必要なリソースとその生産性歩掛を定義してお く。別の見方をすれば，建物情報は案件に依存する情報であり，構 工法知識は案件に依存しない情報である。我々がある設計図を見て A工法を適用した場合の工程はどうなるかと考えるときと，別の設 計図を見てA工法を適用した場合の工程はどうなるかと考えるとき の，A工法の実現の仕方は案件によって異なる。しかし，A工法と 聞いたときに想起する共通部分があるからこそ，それを A工法と称 しているのであり，ここでは，それを構工法知識として定義すると いう意味である。このように定義されうるなら，構工法知識は具体 的な案件によらず，それ自体独立して記述できることになり，さら にそれを同じ言語もしくは互いに可換な言語で記述するなら，構工 法に関する知識を共有し，異なる計画に再利用できることになる。

以上のように, 案件に依存し構工法に依存しない建物情報と，案 件に依存しない構工法知識を分離することを提案する。施エシミュ レーションはこれらの組み合わせに対して行われるわけであるが， これらがきれいに分離されていれば組み合わせの変更は極めて容易 である。つまり，さきほどまで鉄骨系の構工法を適用して計画して いた建物情報に対して, RC系の構工法を適用して計画し直すに障害 はない。これは単に施工計画の作業効率が上がることを意味するだ けでなく，従来の設計情報の中に混在していた性質の異なる二つの 情報を分離することで，情報の可搬性を高めることに通じる。

\section{4. 建物情報の表現}

\section{1 建物情報の要件}

前述したように，建物情報とは部材そのものを表現するのではな く，部材が配置される空間領域を示していると考えれば，そこに断 面情報や仕口情報が必要ないことは明白である。建物情報では部材 がどこに存在しうるのかだけを示せば十分である。単に 3 次元空間 を占める領域の記述でよい。

まず， 3 次元空間に部材を配置する領域を定義するためにはどの ような手段が考えられるか検討する。建物の形状は，水平鉛直に交 差する細長い柱梁の格子状の構造に，水平に広がる床面が何層にも 配置され，それらの最外周を薄い鉛直面が外壁として取り囲むとい うものが典型的なパターンであろう。立体を定義するための様々な 方法が考案されているが，建物を前提とすれば，少数の複雑な数式 で表現するというよりは, 部材ごとの単純な形状を多数配置して, 近接するものは仕口を介して接続すると解するほうが，建築のモデ ル化には自然で，また図形処理の計算コストも小さくすむ。

図形処理とは分割である。上記のような互いに接続された多数の 領域から，柱梁に継手・仕口を設けたり，床をハーフ P Cで割り付 けたり，カーテンウォールを揚重可能サイズに分割したりするなど の処理はすべて，領域の分割で実現する。
3 次元領域の表現には，この分割処理が可能なものを採用しなく てはならない。言い換えれば，一つの 3 次元領域から複数の 3 次元 領域に分割する操作の前後で，同じ表現形式が適用されることが必 要条件となる。その条件は 3 次元領域の表現方法と分割方法の組み 合わせに対して設定される。

部材領域を十分小さい立方体で埋め尽くす表現が一つの選択肢で ある。この場合，切断面に制約はない。どのような曲面で切断しよ うとも, 個々の立方体が切断面のどちら側にいるかを判断するだけ で，新しい領域に分割することができる。ただし，ちょうど切断面 上に存在する立方体は，生成される領域のいずれかに割り振られる わけであるから，その切断面は平滑ではない。切断面を十分平滑に しょうとすれば，立方体のサイズを相応に小さくすることになるが， 概して計算コストの増加を招く。近似を利用せず，平滑な切断面を 実現するためには，立方体でなく，曲面または平面で領域の境界を 示す方法が考えられる。

\section{2 部材の表現と切断}

本論文では，空間領域の表現方法として，部材を包絡する程度の 大きさを持つ 3 次元凸多面体の集合として表現することを提案する。 建物（施エシミュレーションの主要な対象となる躯体）を対象とす る限り，柱，梁，床，壁のような部材は概ね凸多面体で表現できる 上, 計算処理コストも小さくすむ。凸多面体を平面で切断すれば, 切断後の 2 つの領域がやはり凸多面体となるのも都合がよい。

領域の境界は平面で表現されるので，一つの平面で得られる半空 間を $A i: a_{i} x+b_{i} y+c_{i} z+d_{i}<0$ とすれば， $\mathrm{n}$ 個の平面で切り出される ひとつの凸多面体は次のように定義できる。

$$
\begin{gathered}
H=\{(x, y, z) \mid \\
a_{1} x+b_{1} y+c_{1} z+d_{1}<0, \\
a_{2} x+b_{2} y+c_{2} z+d_{2}<0, \\
\quad \vdots \\
\left.a_{n} x+b_{n} y+c_{n} z+d_{n}<0\right\}
\end{gathered}
$$

切断面 $S c: a_{c} x+b_{c} y+c_{c} z+d_{c}=0$ で $H$ を分割して生成されうる領域 は，下の(2)，(3)の両方またはいずれか一方で表される。

$$
\begin{aligned}
& H_{1}^{\prime}=\{\quad(x, y, z) \mid \\
& a_{1} x+b_{1} y+c_{1} z+d_{1}<0, \\
& a_{2} x+b_{2} y+c_{2} z+d_{2}<0, \\
& \vdots \\
& a_{n} x+b_{n} y+c_{n} z+d_{n}<0, \\
& \left.a_{c} x+b_{c} y+c_{c} z+d_{c}<0\right\}
\end{aligned}
$$

$$
\begin{aligned}
& H_{2}^{\prime}=\{(x, y, z) \mid \\
& a_{1} x+b_{1} y+c_{1} z+d_{1}<0, \\
& a_{2} x+b_{2} y+c_{2} z+d_{2}<0, \\
& \quad \vdots \\
& a_{n} x+b_{n} y+c_{n} z+d_{n}<0, \\
& \left.-a_{c} x-b_{c} y-c_{c} z-d_{c}<0\right\}
\end{aligned}
$$

連立不等式を満たす解が存在するかどうかを確認することで， $H^{\prime}{ }^{\prime}$, $H_{2}^{\prime}$ が実際に凸多面体を持つかどうかを判断し，領域を持たないもの は破萧する。解が存在しない場合， $S c$ は $H$ と相貫しなかったこと になり，保存される凸多面体からは不要な $S c$ の情報を削除して， 当初の $H$ を保存する。このような処理によって最終的に得られる凸 多面体ひとつひとつが分割された部材の配置領域となる。

\section{5. 構工法知識の表現}

構工法知識は, 将来生成される様々な建物データに適用するため 


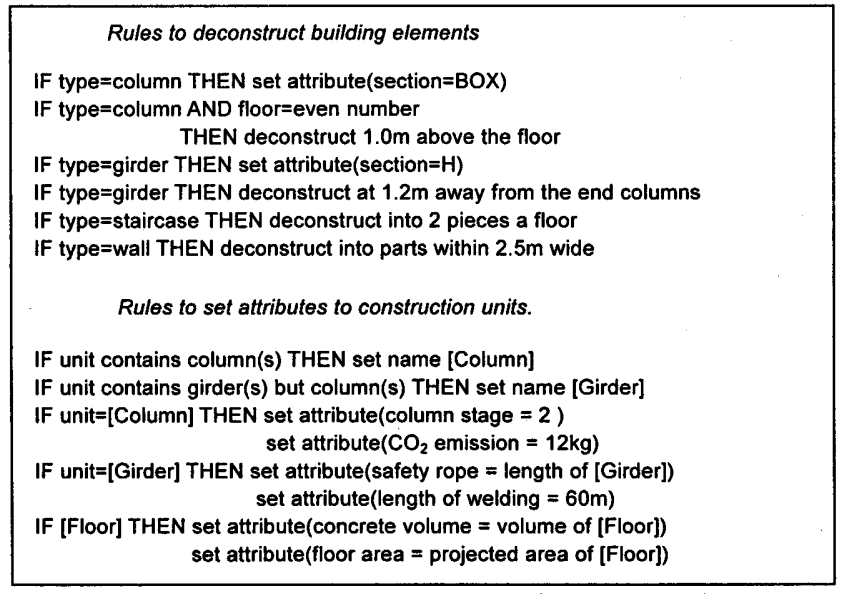

[] means unit consisted of some building elements.

Fig.2: Deconstruction rules

に，案件に依存しない，一般的な記述でなければならない。一般的 な記述とは, 例えば柱の位置について「外周に位置する柱」であり，

$\lceil\mathrm{X} 1$ 通りの柱」は該当しない。「外周に位置する柱」は案件に適用 されるときに初めて具体的な部材として認識されるのである。

工程作成とコスト算出を主目的とした, 躯体の施エシミュレー ションについての筆者の経験から論じれば, 構工法知識として不可 欠なのは, 施工部品の生成ルールと作業（工程）の生成ルールであ る。以下で，それぞれの要素について詳述する。

\section{1 施工部品の生成ルール}

簡単に言えば，その建物がどのような部材のセットで組み立てら れているかを示すことであり, 多くの場合, 工場で生産され建築現 場に搬入される部品の単位を示すものである。鉄骨造などは分かり やすく, 柱は 2 階分または 3 階分の高さをもつ鉛直部分と大梁やブ レースの端部を仕口として一体化された形で現場に搬入される。別 の構工法では, 柱は各階ごとに, 軸部とパネルゾーン部とに分割さ れ，パネルソーンに大梁の端部が一体化される。このように構造形

Class diagram for building elements, groups and activities

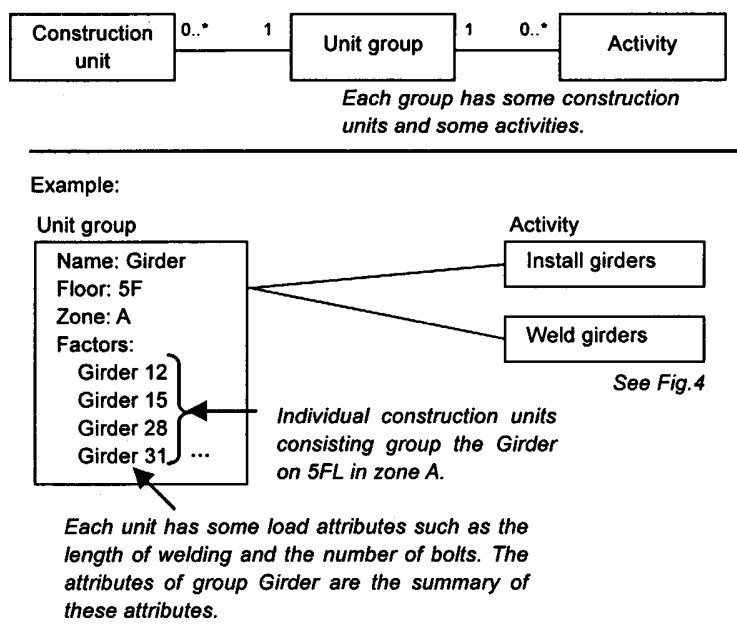

Fig.3: Class diagram for construction units and activities

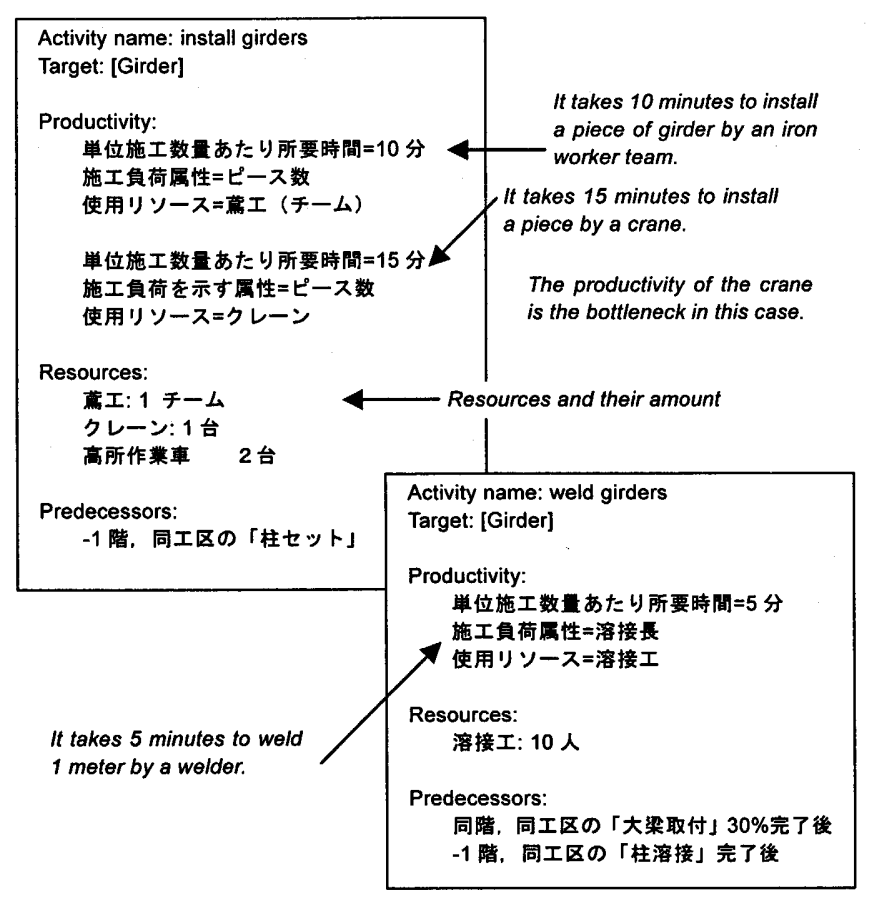

Fig.4: Definition of activities

式によって大きく異なり, 同じ構造形式でもいくつかのバリエー ションがあるのが，部材分割である。

部材分割のルールは Fig.2のように,「偶数階の柱は床から $1 \mathrm{~m}$ 上 で分割される(すなわち, 継手がある)」とか, 「大梁は柱芯から $1.2 \mathrm{~m}$ のところで分割される」などが挙げられる。その応用として，VH 分離工法の R C 造においては, 柱はスラブ下面または梁下面で分割 されることになる。

柱や梁などの部材を分割した後, なお仕口等で接続された一体の 部分は施工部品である。この施工部品に, 工程を作成するための施 工負荷を属性として与える。施工負荷は作業ごとにその対象が異な るので，シミュレーションで扱う作業の時間を算出するのに適切な 属性を与える必要がある。Fig.2 の後半に示したように, 溶接長や ボルト数などはその典型である。また, 工程作成のためでなく, コ スト算出を目的とした仮設材数量や，環境負荷評価を目的とした材 料搬入回数や運搬による二酸化炭素排出量などを属性として与える ことも，この仕組みで可能である。

さらに部材の配置状況や他部材との関係性を条件として,「開口部 まわりの柱は…とか「外壁を支持する大梁は…」のような記述を 許容しなくてはならない。具体的な実装はシステム開発者に委㸚ら れるが，「開口部まわり」であることの判断は，ある部材の直下の階 において, 四方を探索し, 所定の半径内に床部材が存在していない 領域があるかどうかで判断するなどの方法が考えられる。施工計画 を行う際に設計図に基づいて判断できる条件の多くは，このように 空間図形の操作に帰結できる。

部材を適当なグルーブに分類することも寒用上必要である。個々 の部材はそれぞれの形状と取り付け場所を持ち, 区別することがで きる。それら個々に施工負荷属性を与えることもできるが, 実際に は似た部材をひとまとめにして,「柱」「大梁」などと呼び, 作業を このグループに対応させて考えるのが普通である。個々の柱にタス クを割り当てるのではなく，それぞれの大梁がある工区の「大梁」 


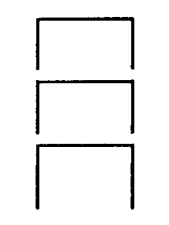

Input of arbitrary 3D model
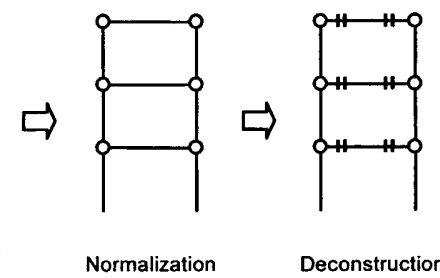

Deconstruction

Deconstruction

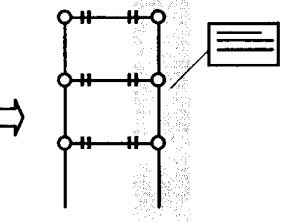

Setting attributes

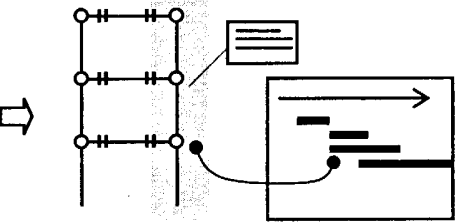

Assignment to schedule

Construction method knowledge is interpreted in these processes.

Fig.5: Simulation processes

グループに含まれ，その「大梁」グループにタスクを割り当てるわ けである (Fig.3)。エレベータや階段まわりの小梁や間柱を「雑鉄 骨」とまとめ,「雑鉄骨揚重」という作業を作ったり, ある階の柱と その直上階の梁をまとめて「鉄骨建方」という作業を作ったりする ことに利用できる。グループをどの程度の大きさにするかはシミュ レーションの方針とそれに伴う作業定義の詳細さに関連することで あり,施工部品単体といった極めて細かい定義から,躯体一式といっ たごく大まかな定義まで様々に考えることができる。

空間図形の操作に帰結できないものも多い。分割操作の後の処理 ではじめて決まるものが条件となる場合, 例えば,「先に取り付けら れる部材」であるかどうかの判断はこの段階ではできないし，1回 の処理では論理的に決まらないことが多い。さらに言えば，仮に処 理を繰り返しても収束しない場合も存在する。本論文で提案する構 工法知識のうち, 部材分割に関するものは, 上記のように単体, ま たは建物の最終形状から真偽が判断できるものに限る。

\section{2 作業の生成ルール}

作業単体を規定するものは, 対象施工部品, 作業を行うために必 要なリソース，およびそれらの組み合わせで決まる生産性歩掛であ る。さらに, 工程の作成には, 複数の作業の先行後続関係が利用さ れる (Fig.4)。

本論文での生産性歩掛（以下，単に歩掛という）は, 単位施工数 量あたりに要する作業時間を使用リソースとの組み合わせによって 表現する。施工数量は対象施工部品を集計することで算出されるが， これは溶接長やコンクリート体積のように, 施工部品に与えられた 属性ごとに算出され，それぞれに歩掛が設定される。通常考えられ る作業については, ボトルネックになる属性とリソースの組み合わ せは常識的に決まっているので，あまり意識されることはないが， 可能性としてひとつの作業に複数の歩掛が与えられることがある。 具体的な例を示す。

鉄骨建方の作業時間は通常，鉄骨のピース数と 1 ピースを取り付 けるためにクレーンを拘束する時閒とで歩掛が設定される。この場 合の歩掛の単位は, (分/ピース/ TC台) であり, 鉄骨のピース数 を乗じることで作業時間が得られる。しかし，作業性が著しく悪い 場合, 蔦工の作業がボトルネックになることもある。この場合,蔦工 1 チームによる建て入れ調整時間が歩掛として意識されるようにな る。歩掛の単位は，(分／ピース／鳯エチーム）である。それぞれの 歩掛で算出されたうち,いずれか長い方の時間が作業の時間となり，
それ以外の時間との差は「待ち」によって埋められる。リソースの 割り当てのバランスが悪い場合に待ちが発生するわけで, 施工管理 者は無駄のないリソース投入量を模索する。作業に考えうる複数の 歩掛を設定しておくことによって, 実際の案件に適用され, 施工数 量が得られたときに，どのリソースが作業を律速しているのかを特 定することができる注2)。

\section{3 作業の先行・後続関係}

作業の先行後続関倸は，いわゆるネットワーク工程表のノードに 表現されるように，極めてシンプルにモデル化することができる。 ノードに複数の入力と複数の出力が許されることから分かるように, 作業の先行後続関係は多対多の多重度をもつ。Finish to Start や Start to Start のような関係に加えて, 時間差や先行作業が一定割 合進捗した時点で後続作業が開始されるという定義も多くのシステ ムで実装されている。作業そのものの時間は施工数量から算出され るため案件に依存し，その結果クリティカルパスは案件に適用する まで分からないが，考えうる制約をすべて記述しておけば，そのす ベての制約を満たす工程が得られる。

ところで, 作業の先行・後続関係は, 「5階の外壁取付は 7 階の鉄 骨建方の後に開始する」のように記述されるが, 案件に依存しない 構工法定義において，階および工区を明示的に指定することはでき ない。そこで, 階についてはオフセットを指定して上下に離れてい る作業を関連付けることとする。先の例で言えば，「n階の外壁取付 は $\mathrm{n}+2$ 階の鉄骨建方の後に開始する」と記述しておくのである。こ れによって, 基準階を繰り返す建物については 1 サイクルの定義だ けで, 基準階の範囲において自動的に工程を生成することが可能に なる。同様に, 工区についても順序を割り当てることで, 相対的な 工区を指定できる。階, 工区が相対的に指定できれば概ねサイクル 工程はおのずと生成できる。

\section{6. システムの実装}

これまでに論じた手法が施工計画に有効であることを実証するた めに, シミュレーション機能をコンピュータプログラムとして実装 した。

建物情報を示す凸多面体として，これを簡略化した直方体を採用 した 注3)。前述したように, シミュレーションの過程で凸多面体は分 割されるのであるから，柱や梁などは同一直線に乗っていれば一つ の直方体で表現してよい。断面が与えられる前であるから, 場所に 
応じて直方体の断面を変化させる必要はない。外壁も同様である。 同じ面を構成しているなら，単一の大きな板で表現すればよい。つ まり，長方形平面の建物であれば 4 つの直方体で覆われることにな る。空の有無やその形式は, 柱や梁に断面を与えるのと同じように, 構工法の一部として, 後の属性付与プロセスで与えることとした。 カーテンウォールの形式は揚重単位や取り付け方法に大きく影響す るので，現実に施エシミュレーションの主要な対象となっている。 建物の平面形状は必ずしも長方形ばかりとは限らないし，長方形平 面であっても，階段室やエレベータシャフト，設備用の床開ロが多 数存在するため, 床スラブは複数の直方体を敷き並べることになる。 高層ビルのように基隻階平面を重ねる構造であれば，基準階を作成 し，図形をコピーする方法でもよい。このような方法であれば，直 方体の数はかなり少なく，しかも断面や継手の位置を気にせずにす むため, 入力工数はきわめて少なく抑えられる。

どのような入力であっても, 直方体が占める領域が同じであれば, シミュレーション結果が同一になるように, シミュレーションの最 初の段階で建物情報の正規化処理を行っている。正規化处理とは， それぞれの直方体が常に同じ処理単位となるように変換する処理で あり，（1）構工法を想定した継手があれば，これを削除する，(2) データ入力上の重複があれば, これを単一化する，（3）近接直方体 どうしに接続情報を持たせる，という一連の処理である。

数値属性は部材やユニットから計算して得られる值や，それを用 いた数式で記述できるようにした。これにより構工法定義がより汎 用的に記述できる。例えば，「クレーンから $15 \mathrm{~m}$ 以上離れている」 という条件を記述するためには，ある点からの距離を部材の平面座 標から計算する必要があるためである。

一つの建物データが複数の構工法に対するシミュレーションが容 易に実行できることを示すため，複数の構工法定義を用意した。
さて，実装したプログラムはこの構工法定義ファイルを読みなが ら，建物情報に対して分割，属性付与といった処理を施し，それら から施工数量を集計し，歩挂とリソースの投入量を乗除することで 作業時間を算出し, 最終的に施工部品を作業に割り当てる, という 処理を行う（Fig.5）。結果, 施工部品, 施工数量, 付与した属性の 集計表が作成され，同時に工程表が得られる。施工部品と作業とが そもそも対応づけられているため, 時間軸に沿ったアニメーション 表現も出力する。

ここで実際に同一の建物データに多数用意されている構工法定義 を適用したシミュレーションを行った。例として, 鉄骨積層工法一 種と RCST 構法一種についての特徵を Table 1 にまとめ, シミュ レーション結果を Fig.6 に示す。ここで得られるサイクル工程, 必 要リソース量の変化, 施工数量とそれに単価を乗じて得られる各種 コストが，構工法を選択する上での判断材料となる。

Table 1: Features of two construction methods

\begin{tabular}{|c|c|c|c|}
\hline & & Method A（鉄盘稓層工法） & Method B (RCST粠法) \\
\hline \multirow[t]{2}{*}{ Structure } & Column & Box-shaped steel & $\begin{array}{l}R C \text { formed by steel tube } \\
\text { (铜管搭て型枠付きRC造) }\end{array}$ \\
\hline & Girder & $\mathrm{H}$-shaped steel & H-shaped steel \\
\hline \multirow[t]{2}{*}{$\begin{array}{l}\text { Elements } \\
\text { and Joints }\end{array}$} & Column & $\begin{array}{l}\text { 3-story long } \\
\text { Welded at } 1 \mathrm{~m} \text { above the floor } \\
\text { Joints on random floors }\end{array}$ & $\begin{array}{l}\text { Deconstructed on every floor } \\
\text { and on every bottom face of } \\
\text { girders }\end{array}$ \\
\hline & Girder & $\begin{array}{l}\text { Non-bracket joint } \\
\text { Welding }\end{array}$ & $\begin{array}{l}\text { Bracket joint } \\
\text { Bolting }\end{array}$ \\
\hline Activities & & $\begin{array}{l}1 \text { Casting of floor concrete } \\
2 \text { Steel frame erection of the } \\
\text { floor } \\
3 \text { Deck, rebar work, and then } \\
\text { casting of the next floor }\end{array}$ & $\begin{array}{l}1 \text { Casting of floor concrete } \\
2 \text { Steel forming } \\
3 \text { Installation of the panel } \\
\text { zones } \\
4 \text { Installation of the girders } \\
\text { between } \\
5 \text { Deck, rebar work and casting }\end{array}$ \\
\hline
\end{tabular}
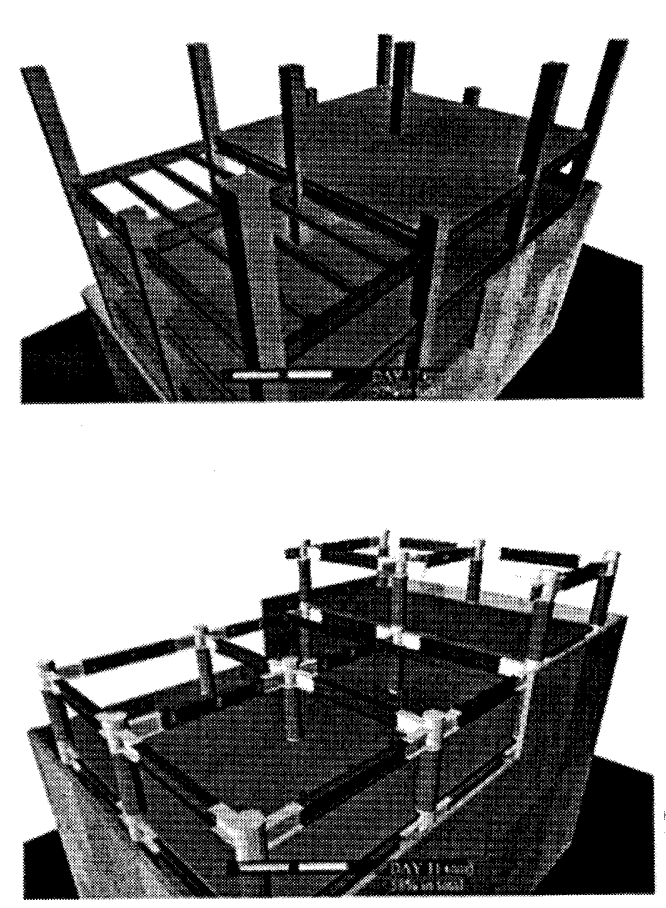

Left top: Deconstruction by method $A$.

Left bottom: Deconstruction by method $B$.

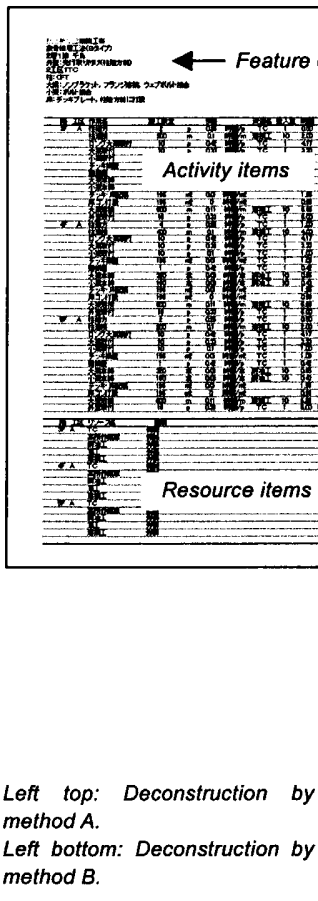

Right top: Bar chart schedule for method A. Right bottom: Quantity takeoff for method $A$.

The total cost is summary of all items calculated as follows:

(Amount) $=$

(Quantity) $\times($ Duration $) \times($ Daily rate $)$ + (Quantity) $\times$ (Fixed rate)

Fig.6: Results of simulation 


\section{7. まとめ}

本論文では，まず施工計画を支援するシミュレーションを実施す るための基本的な考え方として，案件に依存する建物情報と案件に 依存しない構工法知識とを明確に分離することを提案した。建物情 報および構工法知識の表現方法の例として, 躯体の施工について要 求される仕様を示した。併せて，それらのデータを扱う処理系を実 装し，同一の建物データから複数の施エシミュレーションを容易に 実施することが可能なことを示した。こうしたことで，新たな施工 技術が開発されれば，それを構工法として記述することにより施工 に関する知識を蓄積することが可能になったと考える。

構工法知識は, 部材分割, 作業手順, リソースの種類などの組み 合わせであり，組み合わせを変えればそれが新しい構工法定義にな るため，選択肢が増えるにしたがって組み合わせの数は爆発的に增 加する。今回提案した構工法記述手法では解決できない問題であり， 効率よく構工法を記述する方法は課題として残されている。

これまで施工計画についての知識を対象に議論したが，構造設計 に関する知識や環境設計に関する知識を同様に記述することができ れば，ひとつの建物情報を様々な視点で評価する仕組みができる。 これは豊富な情報を盛り込んだ建物モデルを作りこまなくても，設 計の初期段階で建物の多様な評価を可能にするものであり, 設計・ 施工のプロセスに変革をもたらす可能性を鹳している。

ここで示した構工法知識の定義は，いわば施工に関する知識を具 体的に記述したものであり，原始的ではあるが，これまで困難とさ れてきた知識の明文化の一端を担える知見であると考える。

\section{謝 辞}

本論文は，IMS報告書7で発表した構想をもとに，清水建設が出 資者となってスタンフォード大学CIFEに筆者が客員研究員として 在籍した 2003 年から 2005 年に行った研究を中心にまとめたもので ある。

\section{注}

注1）生産性歩掛については 5.2 作業の生成ルール」で示すが，単位施工数量あたりに 要する作業時間を使用リソースとの組み合わせによって表現したものである。

注2）通常は，譲歩できない(增やせない) リソースについて時間を検証し，それに追い つくように他のリソースを必要なだけ投入するという手法がとられる。例えば，夕 ワークレーンを増やすより，溶接工を增やす方が容易であるため，タワークレーン による鉄骨建方の步掛と工程から溶接にかけられる時間 Tを求め，消化しなければ ならない溶接量を，溶接工 1 人日あたりの平均溶接量と時間 $\mathrm{T} て ゙$ 除して，溶接工の 投入人数を決定する。

注3）建築部材を示寸には概ね十分な仕様であるが，不整形な平面の佅や垂直でないファ サードをもつ建物の妻側壁面など，直方体では表現できないものも存在する。

参考文献

1）李興遠，嘉納成男：建築工事の工程シミェレーション結果の視覚化に関する研究 その 2 建築工事の視賞化の試行, 日本建築学会大会学術講演梗概集 F. 建築経済・住宅問 題, pp.857-858, 1991.9

2）松澤健志，ほか 3 名：3 次元データを利用した施工計画／管理支援システムの開発， 第17回情報システム利用技術シンポジウム論文集, pp.37·42, 1994.12

3）嘉納成男，ほか 4 名：パーチャル建設現場システムの開発 建設工事の可視化シミュ レーション，第19回建築生産シンポジウム論文集, pp.95-102, 2003.7

4）北野信吾，ほか 4 名： 4 次元構工法モデリング手法を用いた多工区分割同期化構工法 計画，第18回建築生産シンポジウム論文集，pp.159-166，2002.7

5) Akbas, Ragip: Geometry-based modeling and simulation of construction processes, Ph.D. Thesis, Stanford University, 2003.8

6) 大沢幸雄, 嘉納成男 : 工程編成の要点とその計画アルゴリズムへの展開 施エプロセス チャート手法による工程計画に関する研究 (その1), 日本建築学会計画系論文集, 第 493号, pp.207-214, 1997.3

7) IMS国際共同研究プログラム国内研究開発企画 革新的・知的部品化建設システムの研 究開発に関する研究成果報告書, pp.29-32, (財) 製造科学技術センター, 2002.3

8）山崎雄介，ほか 2 名 : 構法計画と工法計画のインターフェイスに関する研究，第7回建 築生産と管理技術シンポジウム論文集, pp.255·260, 1991.7

9）嘉納成男：工程計画におけるコンピュータ支援に関する研究（その3)自然言語に基つ く計画支援システムの仕組みとプロトタイプ，第14回建築生産シンポジウム， pp.193-198, 1998.7

10) Koo,B. and Fischer,M.: Feasibility study of $4 \mathrm{D}$ CAD in commercial construction, Journal of Construction Engineering and Management, Vol.126, No.4, 2000.7

11) Haymaker,J. and Fischer,M.: Challenges and benefits of $4 \mathrm{D}$ modeling on the Walt Disney Concert Hall Project, Working Paper \#64, Stanford University, Center for Integrated Facility Engineering, 2001.1

\section{Summary}

\section{Introduction}

Preconstruction simulation in 4D helps project participants parse the anticipated problems of their project, but building a 3D model, scheduling the construction processes and linking each 3D object to the schedule is a time-consuming process. It is also difficult to rebuild and resynchronize the model as changes occur. I propose a new way, in which engineers only have to build one 3D model to simulate in many ways with pre-defined computer-readable construction methods.

\section{Separation of Construction Method and Design Information}

The difficulty of altering 4D models comes from the fact that 3D data contains construction information. Once the architect changes the shape of building elements, the engineers rebuild 3D models and reassign them to the schedule. Changing the schedule forces them to reassign elements and schedule again. The solution is separating construction method knowledge and design information as shown in Fig.1. If the construction method information is independent from any individual project, the only thing the engineers have to do is model the 3D data and simulate it using existing method information. Delinking the construction methods from projects can be accomplished by implementing a pre-defined construction method knowledge-base, which accordingly enables the engineers to choose some options from a large number of simulation scenarios. 


\section{Design Information}

Design information should not hold instructions on how to build but directions on what to build. It is true that construction method is a part of design. Without any tentative method, it is impossible to make decisions on material, size of elements and even façade of the building. However, in this paper, attributes such as shapes, materials and the types of joints are eliminated. It is the construction method that shapes these attributes. What building information has to have is a set of spatial areas to fill later with the embodied building elements. I propose that the areas should be expressed in convex hulls. Hulls for columns and girders are connected to each other forming a grid structure. Convex hulls can be disassembled by a plane into multiple convex hulls, which meets the requirement for the deconstruction process discussed later.

\section{Construction Method Definition}

\subsection{Deconstruction and Attribution of 3D Models}

The hulls are deconstructed when a construction method is applied. Each construction method has different types of building elements. A conventional steel structure, for example, has square-columns and $\mathrm{H}-$ shaped beams, which are both steel. The Reinforced Concrete with Steel Tube method, on the other hand, uses round-shaped RC columns cast in thin steel cylinders, $\mathrm{H}$-shaped steel beams and characteristic hybrid panel zones. The types and placement of joints also differ. The conventional steel columns are split every three stories, and their joints are 1 meter above the floor slabs. If the columns have brackets connected to beams, the joints are usually bolted instead of welded. The convex hulls are deconstructed in ways that already describe a construction method (Fig.2). A group of hulls which are still connected each other is a pre-manufactured unit. The attributes such as the bolt counts, the welding length, and the concrete volume are added to the units, which are part of the workload of the activities to calculate the duration.

\subsection{Scheduling}

Activities depend on the construction method, and the workloads of the activities are calculated in accordance with the attributes of building elements. Therefore, the schedule of a construction method describes only the sequence of activities. Each activity has a name, a target element type, production rates, resources, and predecessors (Fig.4). The relationship between element types and activities is expressed as 1:M, which means that an element type has one activity or more and an activity is assigned to only one element type. To calculate the duration of an activity, the system sums up the attributes and multiplies production rates to obtain the biggest number from alternative durations. Installing beams, for example, has two production rates; 15 minutes apiece for a tower crane, and 10 minutes apiece for an iron workers' team. If there are one crane and one team, the duration will be calculated with crane's rate, but with two cranes and one team, the team rate will be used. The activity should have multiple production rates.

\section{Implementation}

To illustrate the concept, I have implemented a prototype system. For simplification, the prototype considers the form of rectangular prisms as design information instead of free convex hulls. The system reads and normalizes a set of prisms, which can be translated from 3D-CAD data, then interprets a construction method file to deconstruct the prisms and add some attributes, and finally produces a quantity takeoff, a schedule, and visualization of the processes over a given timeframe (Fig.5). Table 1 shows the features of two different construction methods, and the result of simulation for these methods is shown in Fig. 6.

\section{Conclusions}

I have proposed a new way to simulate construction processes by separating the construction method and design information. I have also implemented a system to illustrate how this idea works. An extension of this research would be to deeply examine the language and vocabulary for expressing a variety of methods to achieve a thorough construction knowledge-base.

(2006年 5 月 8 日原稿受理，2006年 8 月 9 日採用決定） 